Panetto H., Baïna, S., Morel G. (2007). Mapping the IEC 62264 models onto the Zachman framework for analysing products information traceability: a case study. Journal of Intelligent Manufacturing, Springer Verlag, ISSN 0956-5515, à paraître

\title{
MAPPING THE IEC 62264 MODELS ONTO THE ZACHMAN FRAMEWORK FOR ANALYSING PRODUCTS INFORMATION TRACEABILITY: A CASE STUDY
}

\author{
Hervé Panetto, Salah Baïna, Gérard Morel
}

\author{
Centre de Recherche en Automatique de Nancy (CRAN - UMR 7039), \\ Nancy-University, CNRS, \\ F-54506 Vandoeuvre les Nancy, France, \\ Herve.Panetto@cran.uhp-nancy.fr
}

\begin{abstract}
In order to face new regulation directives regarding the environment and also for improving their customer relationship, enterprises have to increasingly be more able to manage their product information during the entire lifecycle. One of the objectives among others in this paper is to deal with product traceability along the product lifecycle. To meet this objective, the information system has to be designed and, further built in such a way all information regarding products is recorded. The IEC 62264 standards define generic logical models for exchanging product and process information between business and manufacturing levels of enterprise applications. Thus, it can be a base for product information traceability. However, its complexity comes from the fact it mixes conceptual and implementation details while no methodology exists that defines how to instantiate it. Product traceability is then needed to increase its abstraction level in order to concentrate on its concepts and managing its application by providing a methodology for its instantiation. In this paper, we propose to map the IEC 62264 standard models to a particular view of Zachman framework in order to make the framework concrete as a guideline for applying the standard and for providing the key players in information systems design with a methodology to use the standard for traceability purposes.
\end{abstract}

Keywords: Zachman framework, IEC 62264, traceability, products modelling 


\section{INTRODUCTION}

In order to meet the latest worldwide directives imposed for a better environment and a seamless customer relationship, product traceability is now one of the key industrial issues. However, in many scenarios, enterprises encounter the challenging task of enabling coexistence between new and existing systems where product information is dispersed. Industry solutions today have implemented their software architectures on "building block" technology platforms each providing their own competitive advantage within their respective domain. However, with the introduction of these new technology platforms comes the everincreasing complexity of extending these platforms to promote high degrees of interoperability with their respective competitors in order to provide a complete end-to-end business solution that meets the demands of the customer in getting the most accurate information about their product life cycle. Especially, at the level of the production systems, enterprises have to face production data exchange between manufacturing control functions and other enterprise functions. The goal is to reduce the risk, cost, and errors associated with implementing data and model interfaces, enabling enterprise systems and control systems that interoperate and easily integrate.

Standardisation initiatives, either supported by standardisation bodies such as ISO, IEC, or developed by industrial (ISA) or European projects have already attempted to solve this issue. However, each of them focuses on one particular aspect of such interoperability without aligning their enterprise knowledge and skill for taking advantage of a seamless cooperation. However, these standards are closely related to implementation issues and are complex to understand and to put in practice. There is a clear need to make them more abstract and to define methodologies in order to facilitate understanding of their defined concepts.

Many frameworks have been developed in order to concentrate best practices in the development of systems. One of them, the Zachman framework for Enterprise Architecture, (Zachman, 1987; Sowa and Zachman, 1992) offers a static overview of all elements involved 
Panetto H., Baïna, S., Morel G. (2007). Mapping the IEC 62264 models onto the Zachman framework for analysing products information traceability: a case study. Journal of Intelligent Manufacturing, Springer Verlag, ISSN 0956-5515, à paraître

in information systems. However, it is so general and without any concrete guidelines that it is difficult to make it concrete in the development of enterprise applications.

In order to facilitate the instantiation of the IEC 62264 standard models for product information traceability, the objective of this paper is to define abstract views of the models and to propose a methodology based on mapping the IEC 62264 standard models, through a systematic approach, onto the Zachman framework in order to clarify the use of the framework in the context of the product information traceability.

Much effort has been attempted to map different enterprise architecture frameworks and languages onto the Zachman Framework: Sowell (1999) has proposed a mapping of the the views and individual products of the C4ISR Architecture Framework (C4ISR, 1997) to the cells of the Zachman Framework which provides templates and guidelines for modelling the enterprise features with a C4ISR perspective; O'Rourke (2003), in his book, has explained the different Zachman player's views through case studies; Frankel, et al. (2003) have mapped the MDA (Model Driven Architecture) (Mellor, et al., 2004) models used in software development, the UML (Unified Modeling Language) diagrams (UML, 2005) and the many standards related to MDA onto the framework cells in order to facilitate applying the MDA approach for software development; Osvalds (2003) has also proposed some mapping of UML diagrams onto the Zachman framework to provide a traceable methodology for developing architectural models of the enterprise; Noran (2003) has proposed an analysis of the Zachman framework and its mapping onto the Generalised Enterprise Reference Architecture and Methodology (GERAM) framework (ISO IS 15704, 2000) requirements to compare the ability of the Zachman framework to cover the complete scope of the GERAM metamodel, such as life cycle/life history concepts, modelling framework. In some extent, delaHostria (2005) has contributed to this field. He studied how the IEC 62264 may be related to enterprise architecture frameworks by combining it with the ISO 15745 standard 
(ISO 15745, 2003). All these proposals try to compare themselves to the Zachman framework while the proposed work aims to be complementary by defining detailed perspectives of each framework players'view through the IEC 62264 models. Our work is a contribution to the Model Driven Engineering (MDE) (Bezivin, 2004) domain, focused on manufacturing enterprises, which refers to the systematic use of models as primary engineering artefacts throughout the engineering lifecycle. This domain is being considered as an important departure from traditional techniques in such areas as software engineering, system engineering and data engineering.

In order to deal with product traceability information through Product Lifecycle Management (PLM) and related to the various enterprise applications, we consider a product-centric paradigm, as shown in Figure 1 (Baïna, et al, 2005), where the enterprise is composed of two separated worlds: (i) on one hand, a world in which the product is mainly seen as a physical object, this world is called the manufacturing world and it handles systems with manufacturing execution that is tightly related to the shop-floor level, (ii) on the other hand, a world where the product is seen as a service released in the market. This world is called the business world and relates on model-driven product/process engineering. The main issue in product traveability is then to take into account information synchronisation between these two worlds during the system modelling phase.

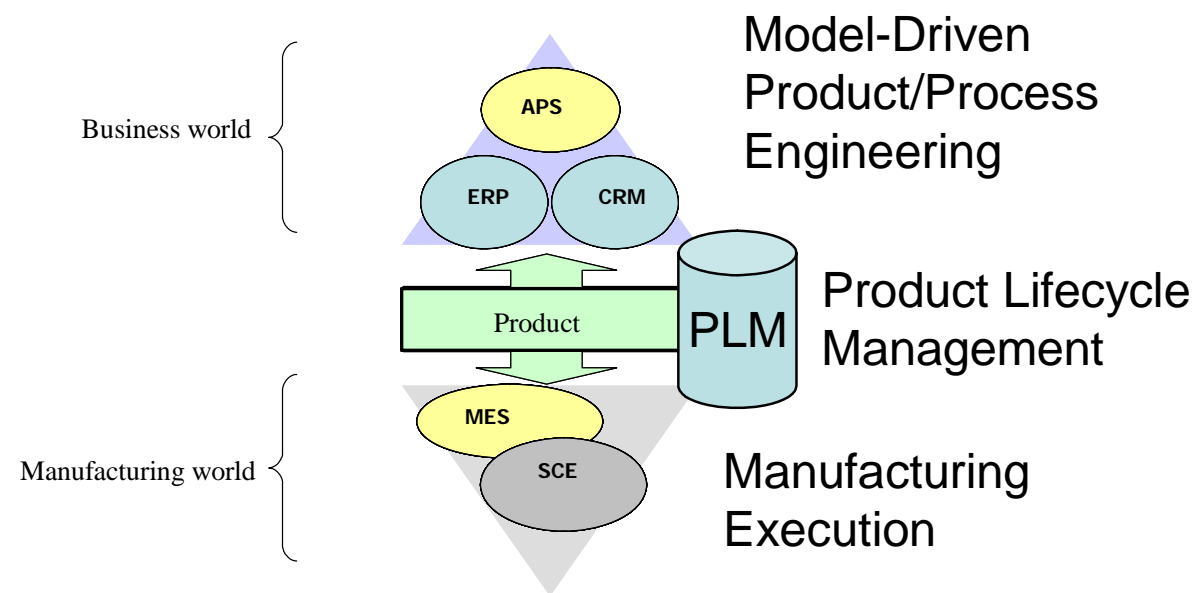

Figure 1: Product-centric paradigm (adapted from (Baïna, et al., 2005) 
Panetto H., Baïna, S., Morel G. (2007). Mapping the IEC 62264 models onto the Zachman framework for analysing products information traceability: a case study. Journal of Intelligent Manufacturing, Springer Verlag, ISSN 0956-5515, à paraître

After presenting, in the next section, the traceability issues in an industrial context, we will give to the reader a brief overview of the IEC 62264 models (section 3) and the Zachman Framework (section 0). Then, we will discuss, in section 5 our mapping of the IEC 62264 models onto the Zachman framework which result in a methodology for instantiating the models based on a generic workflow defining. We will then apply, in section 6, the methodology on an industrial case study and will show the first promising results. Finally, the last section will conclude and will propose further research in this context.

\section{PRODUCT TRACEABILITY}

The term “traceability” related to the product has been defined since the 90's (Cheng and Simmons, 1994), when a series of industrial needs had been highlighted into the establishment of ISO 9000 procedures. Generally, product traceability is the ability of a user (manufacturer, supplier, vendor...) to trace a product through its processing procedures, in a forward and/or backward direction (Jansen-Vullers, et al., 2003). Physically, the product traceability deals with maintaining records of all materials and parts along a defined lifecycle (e.g. from raw material purchasing to finished goods selling) using a coding identification system.

Traceability systems are adopted, according to laws, in the food sector, in manufacturing, in the pharmaceutical sector, in distribution, and in construction. Traceability systems can be useful to increase the quality and safety of the product, for brand protection, and can increase efficiency in production and distribution. Traceability has a different meaning in literature: internal traceability, that is the traceability inside the factory and the production system and external traceability that follows the product into its relations with customers, maintenance, suppliers, etc. (Cheng and Simmons, 1994). Another meaning is between Backward and Forward Traceability (Jansen-Vullers, et al., 2003). Backward Traceability records information and data on the past history of the product. Forward traceability explains what will happen to a certain product, all the processes and output that the product in question 
went into (Terzi, 2005 ; Terzi, et al., 2005). This information is written before production begins and aims to give all the information that are needed to the production. This kind of traceability could be very useful in automated manufacturers (McFarlane, et al., 2005).

The next section will briefly present the IEC 62264 and the abstraction of its models using UML class diagram notations in order to better understand its perspective for product information traceability. Then we will present a brief overview of the Zachman framework before discussing the proposed mapping.

\section{IEC 62264 STANDARD FOR ENTERPRISE-CONTROL SYSTEMS INTEGRATION}

In this section the IEC 62264 (IEC 62264, 2002) standard is presented. This paper will focus, mainly in the first part named "Models and Terminology" which specifies to a set of reference models for information exchange to facilitate the integration of business applications and manufacturing control applications, within an enterprise. The full standard is composed by six different parts designed for defining the interfaces between enterprise activities and control activities. Among all its parts, part 1 describes the relevant functions within an enterprise and within the control domain of an enterprise, stating which objects are normally exchanged between these domains.

Figure 2 depicts the different levels of a functional hierarchy model: business planning and logistics, manufacturing operations and control, and batch, continuous, or discrete control.

The model shows the hierarchical levels at which decisions are made. The interface addressed in the standard is between Level 4 and Level 3 of the hierarchy model. This is generally the interface between plant production scheduling and operation management and the various manufacturing operations and control also known as plant floor coordination. 
Panetto H., Baïna, S., Morel G. (2007). Mapping the IEC 62264 models onto the Zachman framework for analysing products information traceability: a case study. Journal of Intelligent Manufacturing, Springer Verlag, ISSN 0956-5515, à paraître

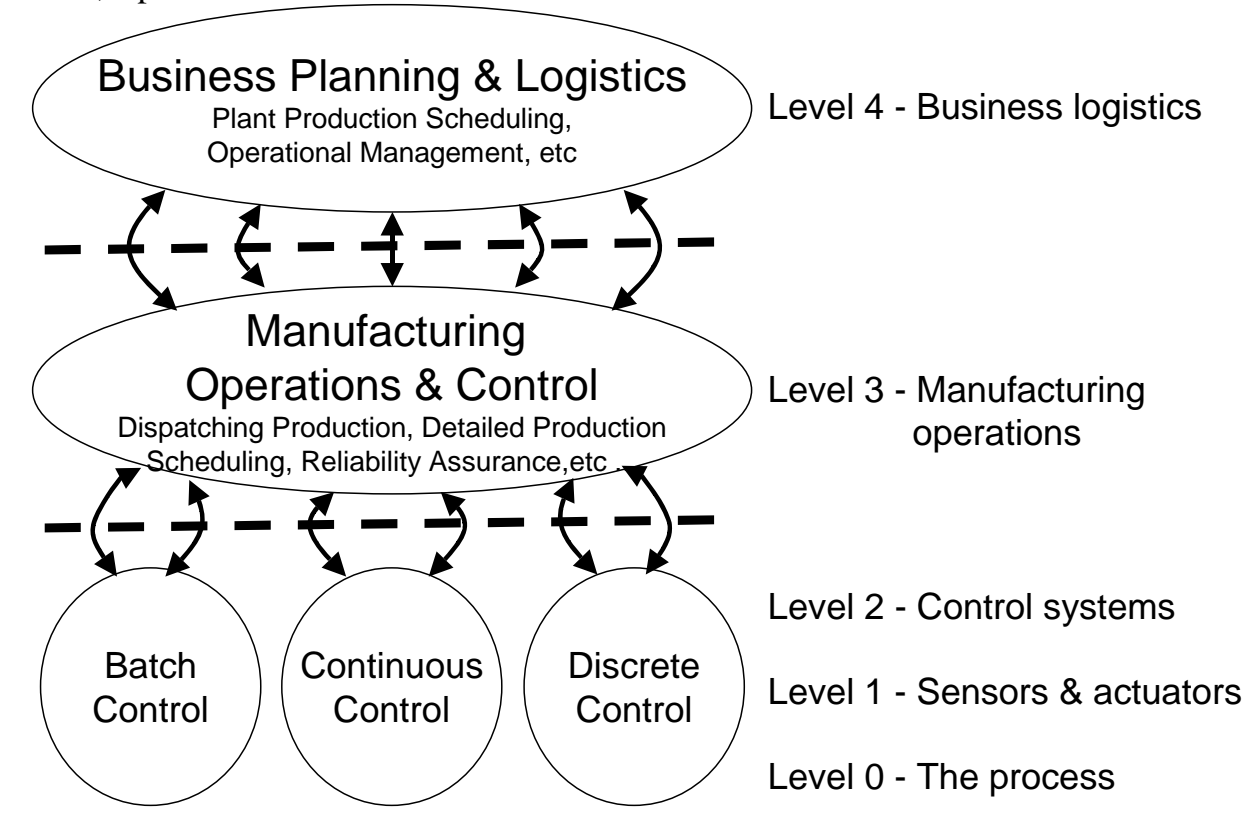

Figure 2: Functional hierarchy as defined in IEC 62264

Levels 2, 1, and 0 present the cell or line supervision functions, operations functions, and process control functions, not addressed by this standard. Level 0 indicates the process, usually the manufacturing or production process. Level 1 indicates manual sensing, sensors, and actuators used to monitor and manipulate the process. Level 2 indicates the control activities, either manual or automated, that keeps the process stable or under control. There are several different models for the functions at these levels based on the actual production strategy used.

The key aspects for integrating the business applications at Level 4 and the manufacturing operations and control applications at Level 2 (and below) are the information structures and exchanges managed by Level 3 activities, applications, processes, resources, and functions. Examples of Level 3 activities include the management of various manufacturing operations, such as, production, maintenance, product quality testing, and material handling. Enterprise applications dealing with these exchanges are, at the business levels, ERP (Enterprise Resource Planning) systems, APS (Advanced Planning and Scheduling) systems, CRM (Customer Relationship Management) systems and, at the manufacturing level, MES (Manufacturing Execution Systems), SCE (Supply Chain Execution) systems. In particular, 
MES functions relate production monitoring, rescheduling and control including production requests and responses, materials (raw and finished) and resources (equipment and personnel) traceability information.

To take into account the various exchanged information, through the product representation, the standard defines a set of eight models that specifies all concepts for enterprise-control integration. Each model concerns a particular view of the integration problem (IEC 62264, 2002).

The different models from IEC 62264 are linked together in a logical way in order to define a hierarchy of models (Figure 3). The production information presents what was made and what was used. Its elements correspond to information in production scheduling that listed what to make and what to use. The production scheduling elements correspond to information in the product definition that shows what is specified to make a product. The product definition elements correspond to information in the process segment descriptions that present what can be done with the production resources. This hierarchy will be the base of our model mapping onto the Zachman framework as proposed in section 5.

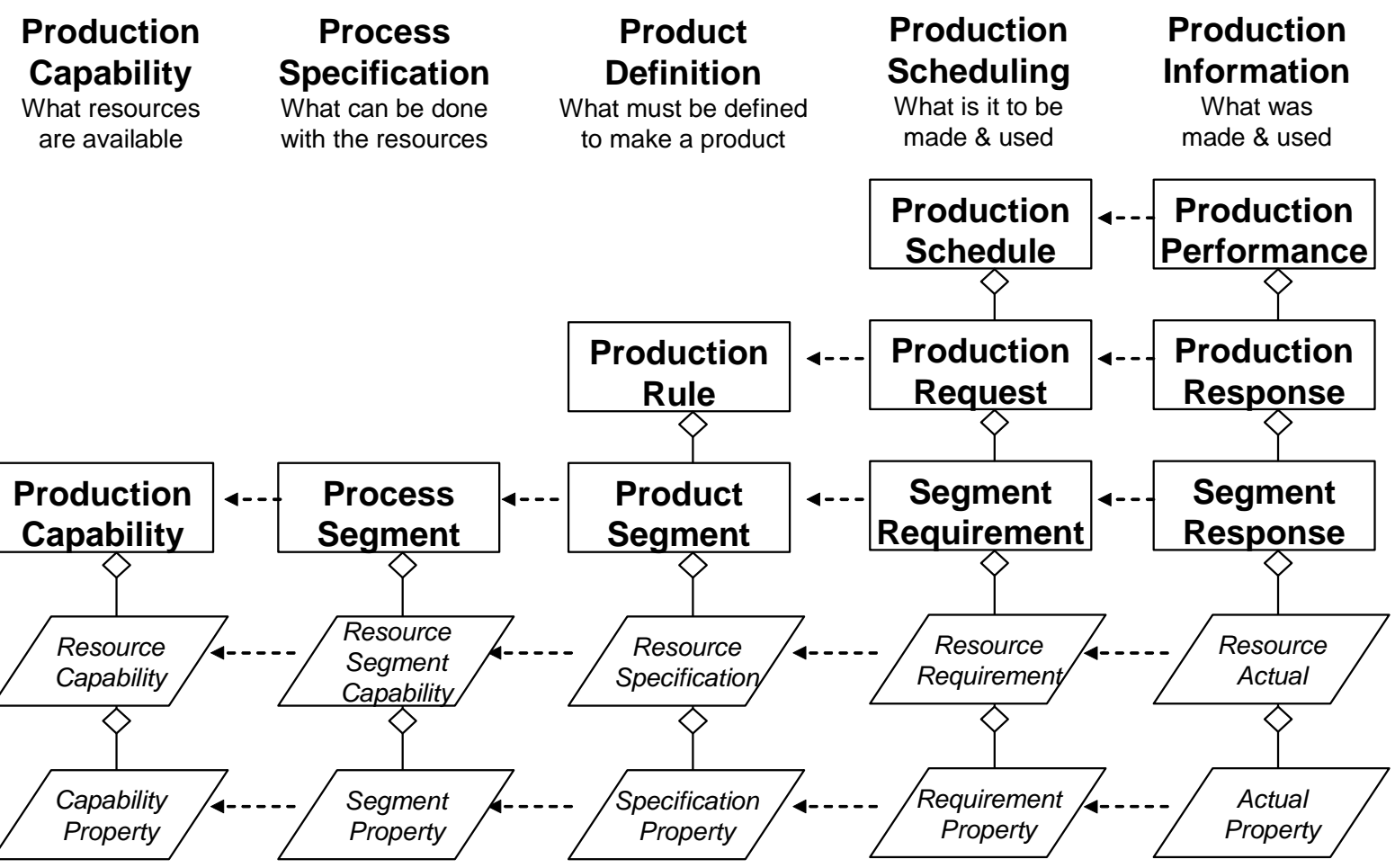

Figure 3: The IEC 62264 models hierarchy (IEC 62264, 2002) 
Panetto H., Baïna, S., Morel G. (2007). Mapping the IEC 62264 models onto the Zachman framework for analysing products information traceability: a case study. Journal of Intelligent Manufacturing, Springer Verlag, ISSN 0956-5515, à paraître

In order to develop the abstraction meaning of the concepts, based on the standard (which is more at a logical level), we have de-normalised and conceptualised its models and then represented them using the UML class diagram notation (only two of them out of the eight available have been reproduced because of the limitation of space):

- Product Definition Model (Figure 5)

The product definition model is information shared between production rules, bill of material, and bill of resources. A product definition contains a listing of the exchanged information about a product. The information is used in a set of product segments that are the values needed to quantify a segment for a specific product. A product segment identifies, references, or corresponds to a process segment. It is related to a specific product, while a process segment is product independent. The collection of product segments for a product gives the sequence and ordering of segments required to manufacture a product in sufficient detail for production planning and scheduling. The corresponding production rule presents the additional detail required for actual production.

- Material Model (Figure 6)

The Material model defines the actual materials, material definitions, and information about classes of material definitions. Material information includes the inventory of raw, finished, and intermediate materials. Material classes are defined to organise materials. A Material definition is a means to describe goods with similar characteristics for purposes of scheduling and planning.

- Equipment Model

The equipment model contains the information about specific equipment, the classes of equipment, equipment capability tests, and maintenance information associated with equipment.

- Personnel Model 
The personnel model contains the information about specific personnel, classes of personnel, and qualifications of personnel.

\section{- Process Segment Model}

The process segment model contains process segments that list the classes of personnel, equipment, and material needed, and/or it may present specific resources, such as specific equipment needed. A process segment may list the quantity of the resource needed. A process segment is related to a product segment that can occur during production, as presented in the product definition model.

- Production Schedule Model

A request for production shall be listed as a production schedule. A production schedule shall be made up of one or more production requests. A request for production for a single product identified by a production rule shall be shown as a production request. A production request contains the information required by manufacturing to fulfil scheduled production. This may be a subset of the business production order information, or it may contain additional information not normally used by the business system. A production request may identify or reference the associated production rule. A production request shall contain at least one segment requirement, even if it spans all production of the product.

- Production Capability Model

The production capability information is the collection of information about all resources for production for selected times. This is made up of information about equipment, material, personnel, and process segments. It describes the names, terms, statuses, and quantities of which the manufacturing control system has knowledge. The production capability information contains the vocabulary for capacity scheduling and maintenance information.

- Production Performance Model

The performance of the requested manufacturing requests shall be listed as production performance. Production performance shall be a collection of production responses. The 
Panetto H., Baïna, S., Morel G. (2007). Mapping the IEC 62264 models onto the Zachman framework for analysing products information traceability: a case study. Journal of Intelligent Manufacturing, Springer Verlag, ISSN 0956-5515, à paraître

responses from manufacturing that are associated with a production request shall be used as production responses. There may be one or more production responses for a single production request if the production facility needs to split the production request into smaller elements of work. A production result may include the status of the request, such as the percentage complete, a finished status, or an aborted status.

In order to facilitate understanding of the UML class diagrams, the Figure 4 summarises the formalism (UML, 2005).

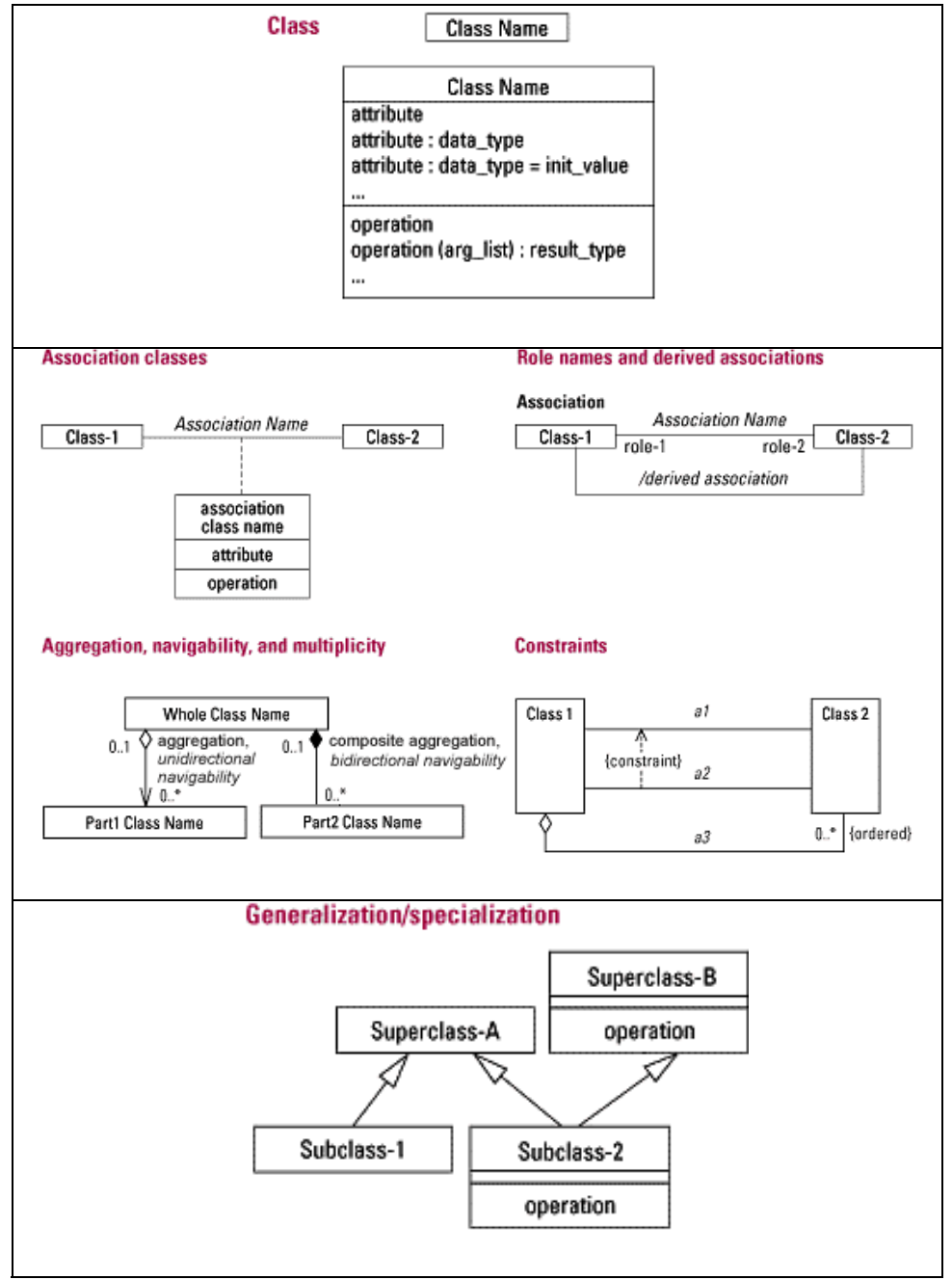

Figure 4: The UML class diagram formalism 


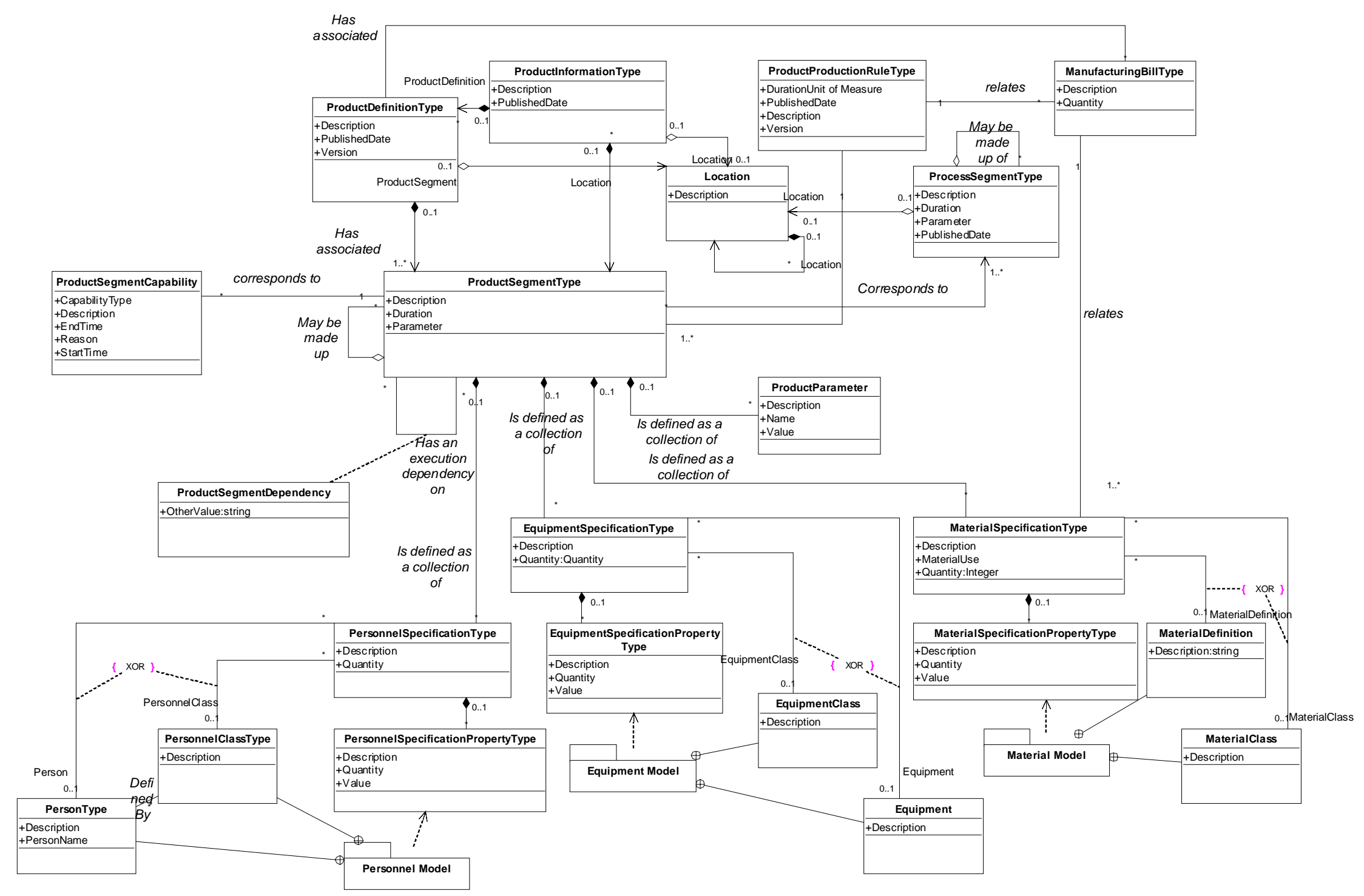

Figure 5: The conceptualised IEC 62264 Product Definition model 
Panetto H., Baïna, S., Morel G. (2007). Mapping the IEC 62264 models onto the Zachman framework for analysing products information traceability: a case study. Journal of Intelligent Manufacturing, Springer Verlag, ISSN 0956-5515, à paraître

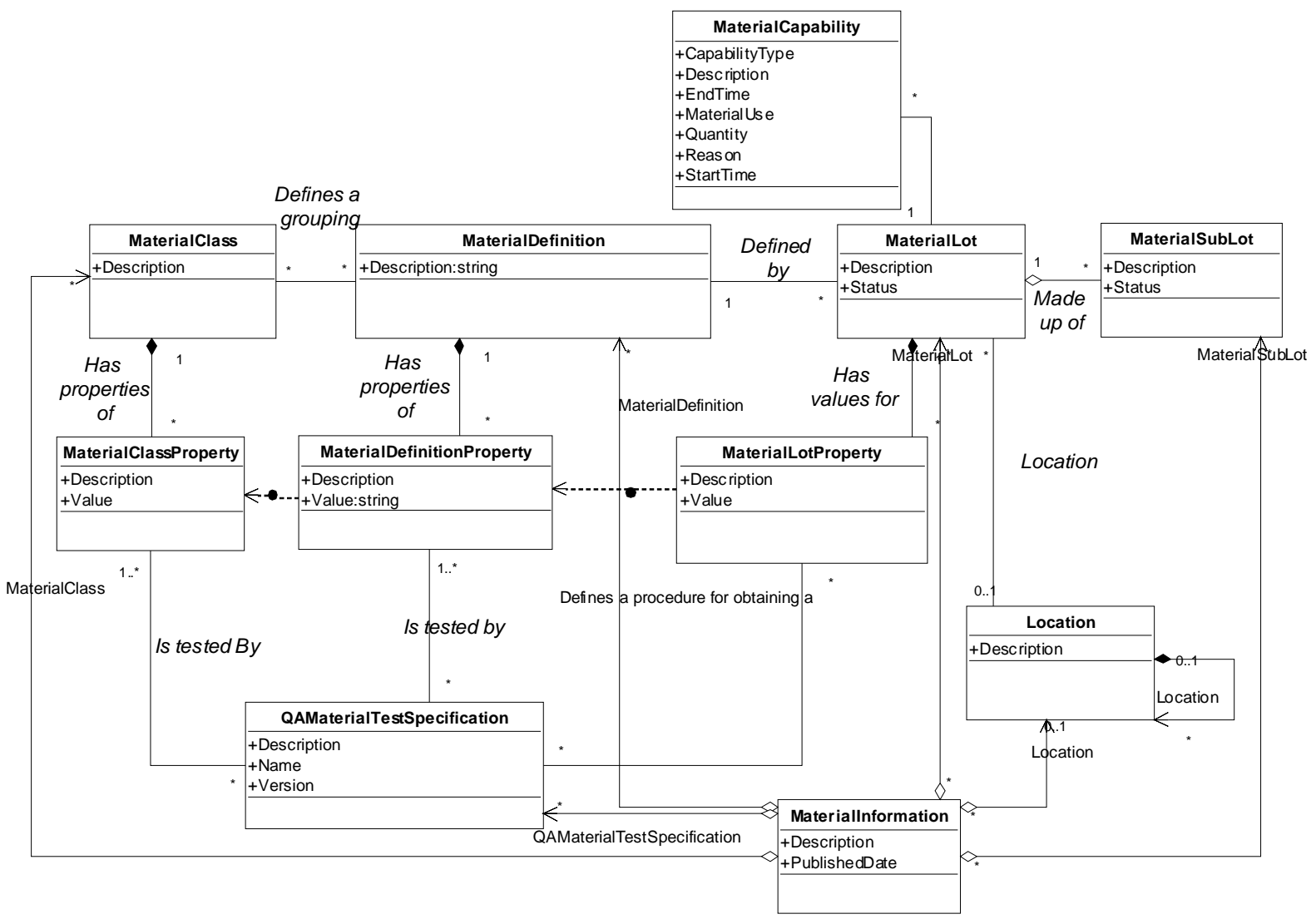

Figure 6: The conceptualised IEC 62264 Material model

\section{THE ZACHMAN FRAMEWORK: A BRIEF OVERVIEW}

In 1987, John Zachman proposed the framework for Enterprise Architecture (Zachman, 1987) and extended it in 1992 (Sowa and Zachman, 1992). Instead of representing the process as a series of steps, he organized it around the points of view taken by the various players (Figure 7). These players included (1) someone who has undertaken to do business in a particular industry, (2) the business people who run the organization, (3) the systems analyst who wants to represent the business in a disciplined form, (4) the designer, who applies specific technologies to solve the problems of the business, (5) the builder of the system, and finally (6) the system itself. He represents each of these perspectives as a row in his matrix. 


\begin{tabular}{|c|c|c|c|c|c|c|c|}
\hline $\begin{array}{l}\text { VA Enterprise } \\
\text { Architecture }\end{array}$ & $\begin{array}{l}\text { DATA } \\
\text { What }\end{array}$ & $\begin{array}{l}\text { FUNCTION } \\
\text { How }\end{array}$ & $\begin{array}{l}\text { NETWORK } \\
\text { Where }\end{array}$ & $\begin{array}{l}\text { PEOPLE } \\
\text { Who }\end{array}$ & $\begin{array}{l}\text { TIME } \\
\text { When }\end{array}$ & $\begin{array}{l}\text { MOTIVATION } \\
\text { Why }\end{array}$ & $\begin{array}{l}\text { Based on work by } \\
\text { John A. Zachman }\end{array}$ \\
\hline $\begin{array}{l}\text { SCOPE } \\
\text { (What is important } \\
\text { for the enterprise) }\end{array}$ & $\begin{array}{l}\text { Things Important } \\
\text { to the Business }\end{array}$ & $\begin{array}{l}\text { Processes } \\
\text { Performed }\end{array}$ & $\begin{array}{l}\text { Business } \\
\text { locations }\end{array}$ & Organizations & $\begin{array}{l}\text { Events Significant } \\
\text { to the Business }\end{array}$ & $\begin{array}{l}\text { Business Goals } \\
\text { and Strategy }\end{array}$ & $\begin{array}{l}\text { SCOPE } \\
\text { (What is important } \\
\text { for the enterprise) }\end{array}$ \\
\hline Planner & $\begin{array}{l}\text { Entity = Class of } \\
\text { Business Thing }\end{array}$ & $\begin{array}{l}\text { Function }=\text { Class of } \\
\text { Business Process }\end{array}$ & $\begin{array}{l}\text { Node }=\text { Major } \\
\text { Business Locations }\end{array}$ & $\begin{array}{l}\text { People }=\text { Major } \\
\text { Organizations }\end{array}$ & $\begin{array}{l}\text { Time }=\text { Major } \\
\text { Business Event }\end{array}$ & $\begin{array}{l}\text { Ends/Means = } \\
\text { Major Business Goals }\end{array}$ & Planner \\
\hline $\begin{array}{l}\text { ENTERPRISE } \\
\text { MODEL } \\
\text { (What is available) }\end{array}$ & Semantic Model & $\begin{array}{l}\text { Business Process } \\
\text { Model }\end{array}$ & $\begin{array}{l}\text { Business Logistics } \\
\text { System }\end{array}$ & Work Flow Model & Master Schedule & 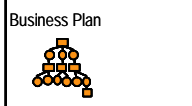 & $\begin{array}{r}\text { ENTERPRISE } \\
\text { MODEL } \\
\text { (What is available) }\end{array}$ \\
\hline Owner & $\begin{array}{l}\text { Ent }=\text { Business Entity } \\
\text { Rel }=\text { Business Relationship }\end{array}$ & $\begin{array}{l}\text { Proc }=\text { Business Process } \\
1 / O=\text { Business Resources }\end{array}$ & $\begin{array}{l}\text { Node }=\text { Business Location } \\
\text { Link }=\text { Business Linkage }\end{array}$ & $\begin{array}{l}\text { People }=\text { Organization Unit } \\
\text { Work }=\text { Work Product }\end{array}$ & $\begin{array}{l}\text { Time }=\text { Business Event } \\
\text { Cycle }=\text { Business Cycle }\end{array}$ & $\begin{array}{l}\text { End = Business Objective } \\
\text { Means = Business Strategy }\end{array}$ & Owner \\
\hline \begin{tabular}{|l|} 
SYSTEM MODEL \\
(How to build products)
\end{tabular} & $\begin{array}{l}\text { Logical Data } \\
\text { Model } \\
\square=\square \\
\square \\
\text { Ent = Data Entity } \\
\text { Rel = Data Relationship }\end{array}$ & $\begin{array}{l}\text { Application } \\
\text { Architecture } \\
\text { Proc = Application Function } \\
1 / O=\text { User Views }\end{array}$ & $\begin{array}{l}\text { Distributed System } \\
\text { Architecture } \\
\text { Node = IS Function } \\
\text { Link = Line Characteristics }\end{array}$ & $\begin{array}{l}\text { Human Interface } \\
\text { Architecture } \\
\text { 몰 } \\
\text { People = Role } \\
\text { Work = Deliverable } \\
\end{array}$ & $\begin{array}{l}\text { Processing } \\
\text { Structure }\end{array}$ & $\begin{array}{l}\text { Business Rule } \\
\text { Model } 10 \\
\\
\text { End = Structural Assertion } \\
\text { End } \\
\text { Means = Action Assertion }\end{array}$ & $\begin{array}{c}\text { SYSTEM MODEL } \\
\text { (How to build products) } \\
\text { Designer }\end{array}$ \\
\hline $\begin{array}{l}\text { TECHNOLOGY } \\
\text { MODEL } \\
\text { (How to implement) }\end{array}$ & Physical Data & $\begin{array}{l}\text { System } \\
\text { Design } \\
\text { 몰 }\end{array}$ & $\begin{array}{l}\text { Technology } \\
\text { Architecture } \\
\text { 留一間 }\end{array}$ & $\begin{array}{l}\text { Presentation } \\
\text { Architecture }\end{array}$ & $\begin{array}{l}\text { Control } \\
\text { Structure }\end{array}$ & 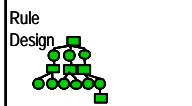 & $\begin{array}{r}\text { TECHNOLOGY } \\
\text { MODEL } \\
\text { (How to implement }\end{array}$ \\
\hline Builder & $\begin{array}{l}\text { Ent }=\text { SegmentT Table } \\
\text { Rel }=\text { Pointer/Key }\end{array}$ & $\begin{array}{l}\begin{array}{l}\text { Proc }=\text { Computer Function } \\
1 / O=\text { Data Elements } / \text { Sets }\end{array} \\
\text {. }\end{array}$ & $\begin{array}{l}\text { Node }=\text { Hardware/Software } \\
\text { Link = Line Specifications }\end{array}$ & $\begin{array}{l}\text { People }=\text { User } \\
\text { Work }=\text { Screen Format }\end{array}$ & $\begin{array}{l}\text { Time }=\text { Execute } \\
\text { Cycle }=\text { Component Cycle }\end{array}$ & $\begin{array}{l}\text { End }=\text { Condition } \\
\text { Means }=\text { Action }\end{array}$ & Builder \\
\hline \begin{tabular}{|l|} 
DETAILED \\
REPRESENTATIONS
\end{tabular} & 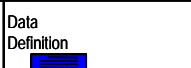 & Program & $\begin{array}{l}\text { Network } \\
\text { Architecture }\end{array}$ & $\begin{array}{l}\text { Security } \\
\text { Architecture }\end{array}$ & Timing & $\begin{array}{l}\text { Rule } \\
\text { Design }\end{array}$ & $\begin{array}{r}\text { DETAILED } \\
\text { REPRESENTATIONS }\end{array}$ \\
\hline Sub-Contractor & $\begin{array}{l}\text { Ent }=\text { Field } \\
\text { Rel }=\text { Address }\end{array}$ & $\begin{array}{l}\text { Proc }=\text { Language Statement } \\
1 / O=\text { Control Block }\end{array}$ & $\begin{array}{l}\text { Node }=\text { Addresses } \\
\text { Link }=\text { Protocols }\end{array}$ & $\begin{array}{l}\text { People = Identity } \\
\text { Work = Job }\end{array}$ & $\begin{array}{l}\text { Time }=\text { Interrupt } \\
\text { Cycle }=\text { Machine Cycle }\end{array}$ & $\begin{array}{l}\text { End = Sub -Condition } \\
\text { Means = Step }\end{array}$ & Sub-Contractor \\
\hline \multirow[t]{3}{*}{$\begin{array}{l}\text { FUNCTIONING } \\
\text { ENTERPRISE }\end{array}$} & Data & Function & Network & Organization & Schedule & Strategy & $\begin{array}{r}\text { FUNCTIONING } \\
\text { ENTERPRISE }\end{array}$ \\
\hline & $\begin{array}{l}\text { Ent }= \\
\text { Rel }=\end{array}$ & $\begin{array}{l}\text { Proc }= \\
1 / O=\end{array}$ & $\begin{array}{l}\text { Node }= \\
\text { Link }=\end{array}$ & $\begin{array}{l}\text { People = } \\
\text { Work = }\end{array}$ & $\begin{array}{l}\text { Time }= \\
\text { Cycle }=\end{array}$ & $\begin{array}{l}\text { End = } \\
\text { Means = }\end{array}$ & \\
\hline & $\begin{array}{l}\text { DATA } \\
\text { What }\end{array}$ & $\begin{array}{l}\text { FUNCTION } \\
\text { How }\end{array}$ & $\begin{array}{l}\text { NETWORK } \\
\text { Where }\end{array}$ & $\begin{array}{l}\text { PEOPLE } \\
\text { Who }\end{array}$ & $\begin{array}{l}\text { TIME } \\
\text { When }\end{array}$ & $\begin{array}{l}\text { MOTIVATION } \\
\text { Why }\end{array}$ & \\
\hline
\end{tabular}

Figure 7: The Zachman framework matrix

He then acknowledged that each of these participants is looking at the same categories of information. If the roles are represented by rows in a matrix, the things examined can be represented by columns. Specifically, the columns represent the data manipulated by an organization (what), its functions and processes (how), locations where business is conducted (where), events that trigger business activities (when), the people and organizations involved (who), and the motivations and constraints which determine how the business behaves (why).

The set of cells thus defined turn out to house all the various modelling techniques we use in the information processing industry. Moreover, they identify some places where we could use some new models. In addition, the translations required to go from row to row reveal interesting things about both how we do and how we should do our business. The Zachman framework however is not sufficient as a practical framework for enterprise architecture. The Zachman framework offers a static overview of all elements involved in information systems. It does not define the processes to go from an existing (as-is) situation to a future (to-be) state and neither does it define an organisation to support such processes. 
Panetto H., Baïna, S., Morel G. (2007). Mapping the IEC 62264 models onto the Zachman framework for analysing products information traceability: a case study. Journal of Intelligent Manufacturing, Springer Verlag, ISSN 0956-5515, à paraître

The framework does identify the exhaustive list of possible documentation standards but does not define their content or gives examples. Therefore one could conclude that the Zachman Framework for Enterprise Architecture serves as a checklist ensuring that all aspects involved in information systems have been taken into account. As a reference frame it is not sufficient as it needs to be complemented by the process and organisational aspects in addition to examples of the actual documentation standards. What does it mean to view the development process in these terms? The major contribution of the framework is its explicit recognition that there is more at work here than functions and data.

From the beginning, we should be recognizing the organizational issues; from the beginning, we should be dealing with multiple locations; from the beginning we should be explicitly concerned with timing - triggers, schedules, and so forth. We do not have models, or even well developed methods for dealing with many of the cells. Zachman does not advocate the use of any particular modelling style for those cells where multiple techniques are available, and he is the first to recognize that in some cells no good techniques exist. It is difficult, for example, to model the logic (row three) of a distributed information network - at least in a way that links to our models for functions and data. This represents an assignment for us all. He has pointed out things that we should be capturing and accounting for in our systems. It is for us to figure out how to do so.

More details on the Zachman framework may be found on the ZIFA web site (http://www.zifa.com).

\section{MAPPING THE IEC 62264 MODELS ONTO THE ZACHMAN FRAMEWORK FOR PRODUCTS INFORMATION TRACEABILITY}

This work proposes to make concrete the use of the Zachman framework as a guideline for instantiating the conceptual IEC 62264 models and hence, defining the whole set of information related to the products during their life cycle. This work is complementary to the 
MDA $^{\mathrm{TM}}$ approach (Model Driven Architecture) (Mellor, et al., 2004) proposed by OMG which allows separation of platform dependent from platform independent aspects in systems applications construction and maintenance.

The current IEC 62264 standard models are, with regards to the abstraction view (Figure 8), at a logical level - what the MDA calls PIM (Platform Independent Model) - because, related to a normative point of view, they need to be closer to the implementation and linked to the execution level (Functioning view).

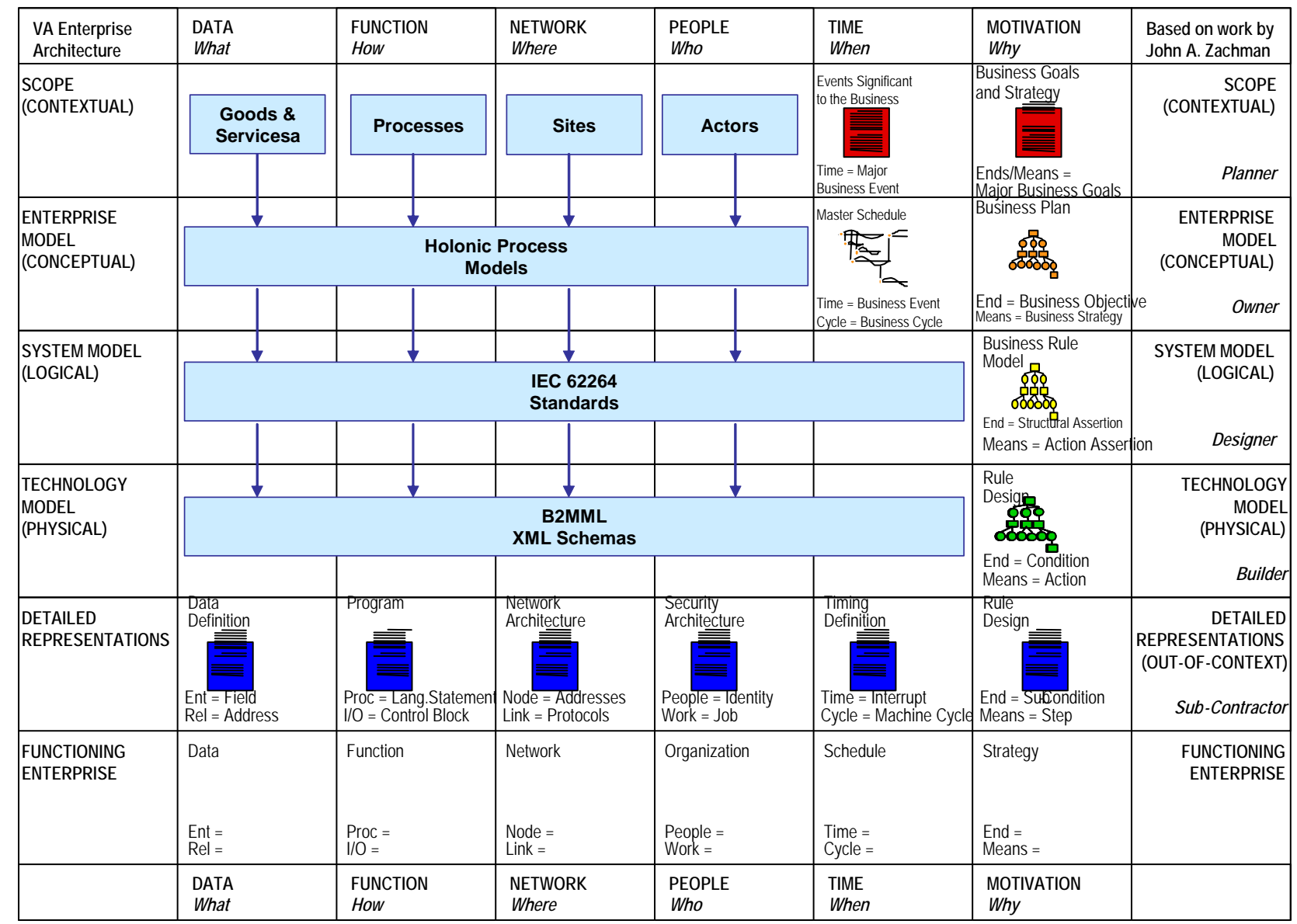

Figure 8: IEC 62264 standards on the Zachman abstraction view

However, by conceptualising them and mapping them onto the Zachman framework players view, we put forward their conceptual invariants that may be seen as the MDA calls the CIM level (Computerisation Independent Model). In such case, the modeller (the player) is strengthening the information requirements for product traceability, forgetting then the implementation issues. In our case, the Zachman framework will then be used as a filter and a guideline to recognize what models, used by which distinct groups, with different points of view, have to be applied in order to specify the product information, along the product life 
Panetto H., Baïna, S., Morel G. (2007). Mapping the IEC 62264 models onto the Zachman framework for analysing products information traceability: a case study. Journal of Intelligent Manufacturing, Springer Verlag, ISSN 0956-5515, à paraître

cycle, for ensuring traceability. As Sowa and Zachman (1992) pointed out: the recursiveness of the framework is possible. It is the possibility of applying the logic of the framework to the framework itself. That is, any given cell is a complex engineering product in its own right. It has an owner, designer, builder, material, function, and geometry. Therefore, the framework logic could be applied to each of the cells of the framework (or rows) to analyse the design and construction issues that affect that cell (that row) with a new perspective related to the players view (Figure 9). The player view is recursively a Zachman matrix related to one cell (or row) of the initial matrix 


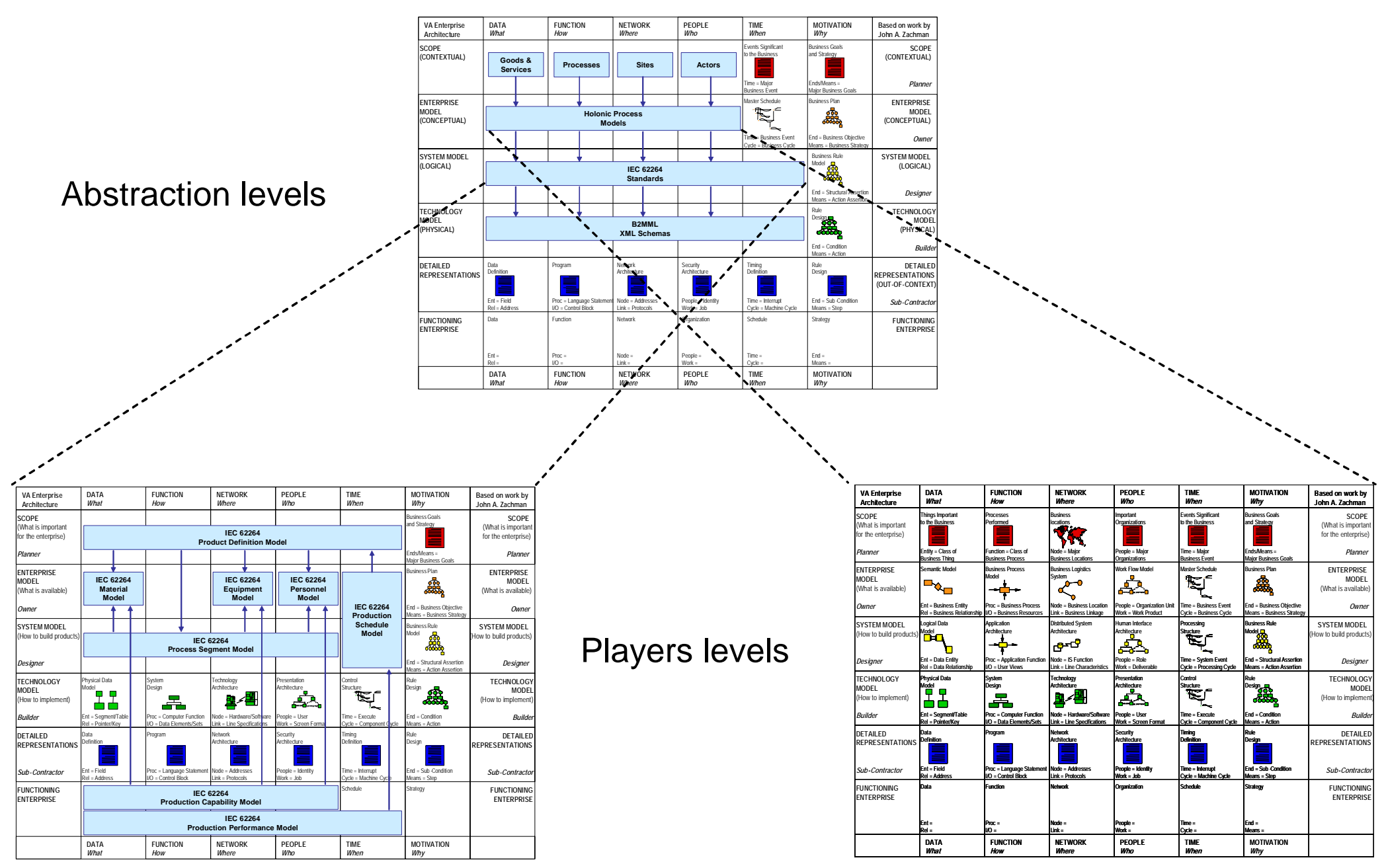

Figure 9: Zachman recursive views 
Panetto H., Baïna, S., Morel G. (2007). Mapping the IEC 62264 models onto the Zachman framework for analysing products information traceability: a case study. Journal of Intelligent Manufacturing, Springer Verlag, ISSN 0956-5515, à paraître

Indeed, Sowa and Zachman (1992) proposed a set of rules when using their framework. The logic structure or rules of the framework are generic. They can be used for structuring the description of any complex object. The framework was first discovered by observing how the manufacturing discipline segments the descriptions of complex engineering products for the purpose of design and manufacture. Two of these rules strengthen the recursive perspective of the framework:

- The composite or integration of all cell models in one row constitutes a complete model from the perspective of that row.

- The logic is recursive. The framework logic can be used for describing virtually anything, certainly anything that has an owner, designer, and builder who makes use of material, function, and geometry. The logic was initially perceived by observing the design and construction of buildings.

Thus, the Zachman framework could be seen as a way to define different models at different abstract levels, for different purposes, or, as a filter that enables, through different views, to specify what has to be modelled in relation to the player in the IT organisation. The framework will then support a kind of methodology when one would like to instantiate a set of related models such as the IEC 62264 standard. The result will be a better formalisation about what each model is dealing with and the relationships between them with regards to a specific need: in our case, the modelling of product information traceability.

We then take into account mainly the players' view of the models who will be guided by the framework to ensure that all aspects involved in product information traceability have been taken into account during the modelling phase. Indeed, we mapped the eight IEC 62264 models onto the framework and, we defined some preliminary logical relationships between them in order to facilitate the definition of the product information traceability (Figure 10). 


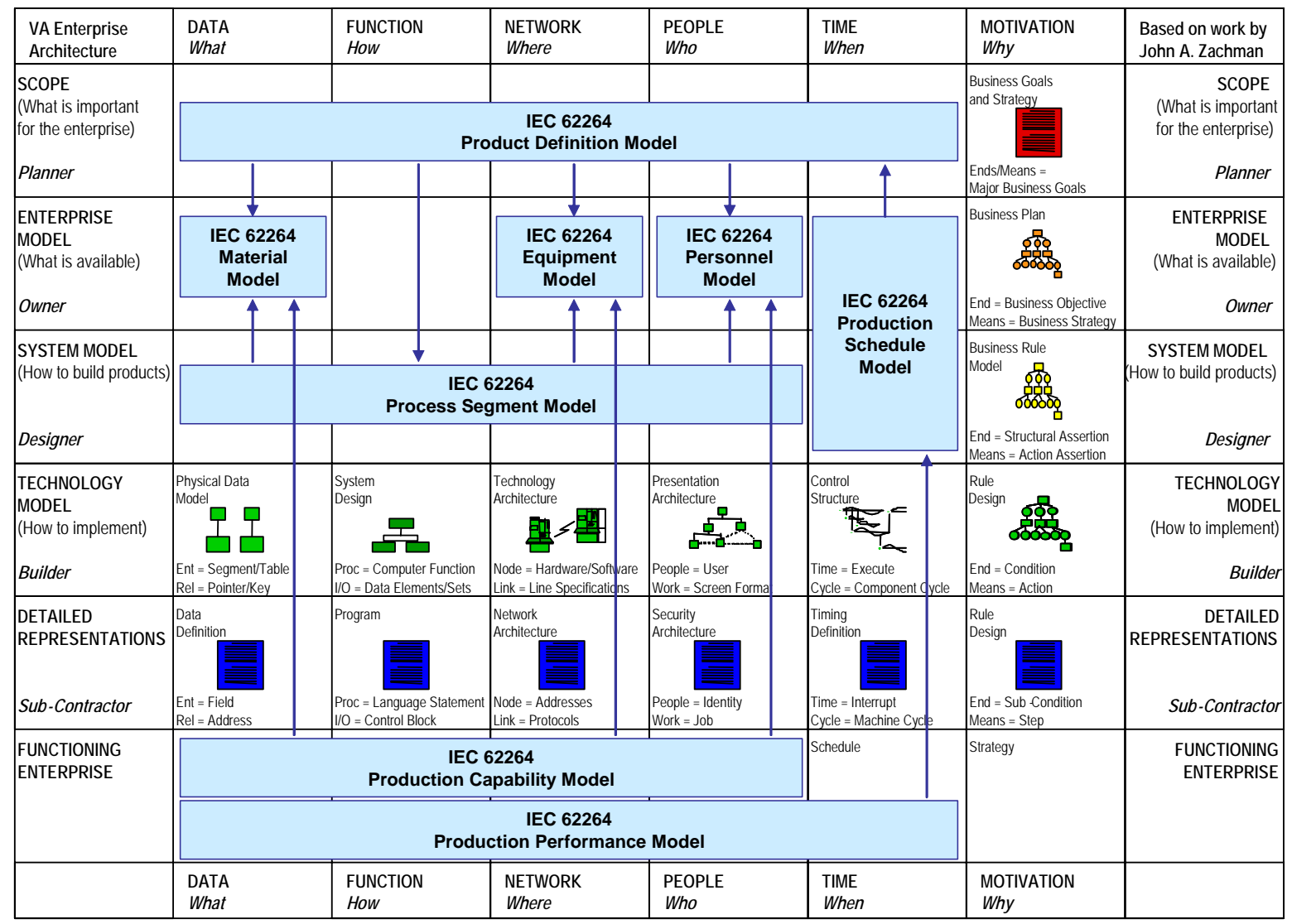

Figure 10: IEC 62264 models mapped onto the Zachman framework players view

Let us now explain, line by line, model by model, what our mapping will bring. In Figure 10, the arrows have the semantics of "has a reference to"; for example, the "Product Definition Model" has references to the "Material Model", the "Equipment Model”, the "Personnel Model” and the "Process Segment Model”.

The first line of the framework, related to the planner view, concerns the things that define the nature and purpose of the enterprise and what is important for the enterprise. It is related to the product definition and the needed resource specifications. This is exactly the definition of the IEC 62264 "Product definition model" that defines product segments which identify the products, their location, their references, and the resources needed to produce them. The second line defines the enterprise model comprised of the nature of the available manufacturing and business components including the structure, functions and organization. The IEC 62264 specifies the enterprise model by hierarchies related to the materials (raw, consumed, finished ...), the equipment and the personnel available for production. The product definition reference resources as needed for specific products while the process 
Panetto H., Baïna, S., Morel G. (2007). Mapping the IEC 62264 models onto the Zachman framework for analysing products information traceability: a case study. Journal of Intelligent Manufacturing, Springer Verlag, ISSN 0956-5515, à paraître

segments reference them as available resources for production. The third line of the framework, related to the designer view, defines the available processes and their information process and how to build products. In our context, this level relates to the process segments that list the classes of personnel, equipment, and material needed, and/or present specific resources, such as specific equipment needed. The scheduling and decomposition of process segments with regards to the available resources is specified, in IEC 62264, by the "Production Schedule Model" that crosses the second and third lines of the framework. Indeed, scheduling means synchronising resource availability and product definitions in order to deal with time constraints. The fourth and fifth lines of the framework are out of our scope with regards to product traceability. Indeed, they relate to the builder view and its subcontractors and are used for defining the system development process.

Finally, the "Functioning Enterprise" line of the framework, which is usually forgotten by modellers, is important for our scope because it defines how real time information related to the production capability and production performance is modelled in relationship with the enterprise model and the production schedule. It is the place where most of the information is produced in order to record the product genealogy and its life history.

The Zachman framework is, as explained, a filter that provides the questions, related first to the abstraction levels of the models and, secondly to the different players, to fill the model instances (Figure 11). 


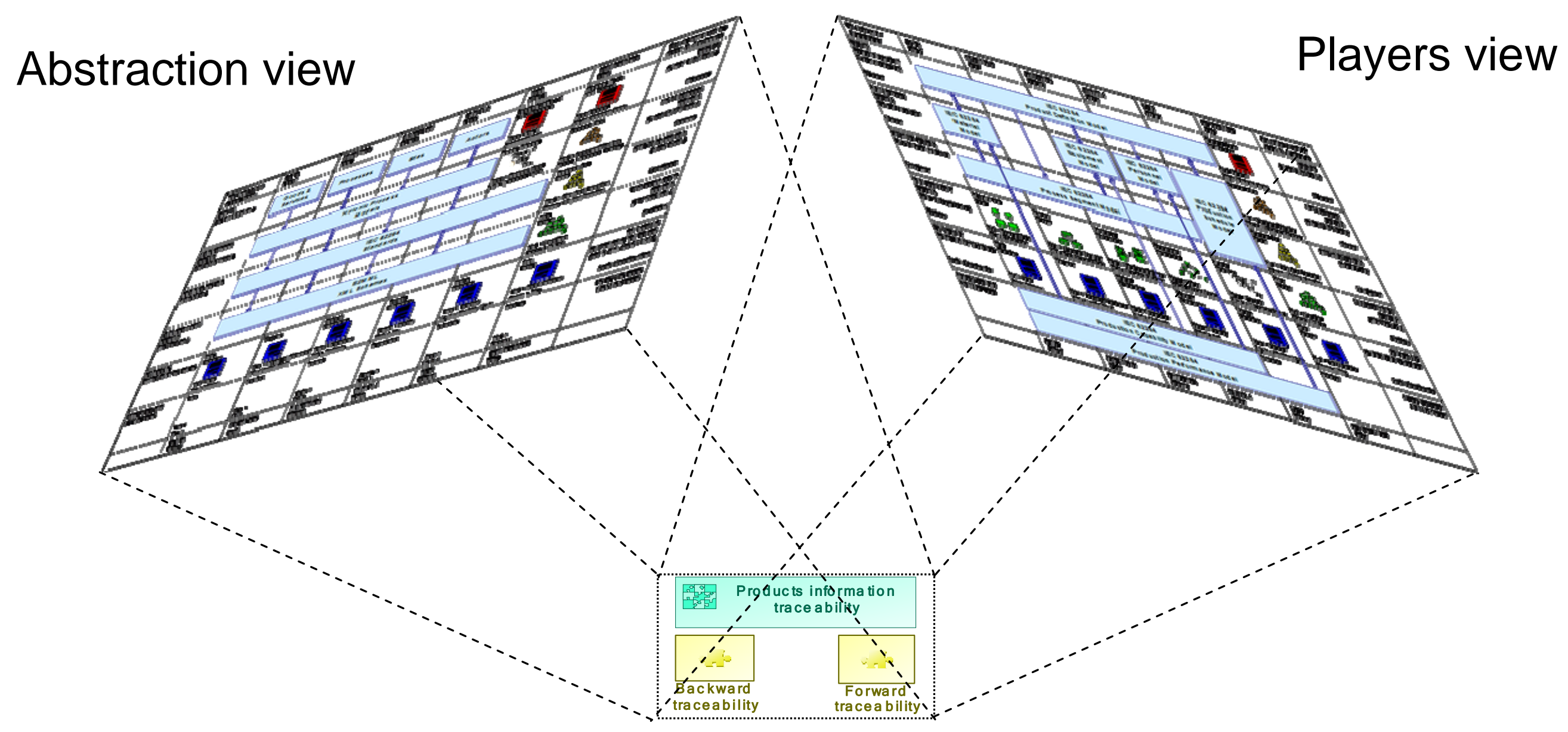

Figure 11: The Zachman framework as a filter for views definition of products information traceability models. 
Panetto H., Baïna, S., Morel G. (2007). Mapping the IEC 62264 models onto the Zachman framework for analysing products information traceability: a case study. Journal of Intelligent Manufacturing, Springer Verlag, ISSN 0956-5515, à paraître

Zachman does not advocate the use of any particular modelling style and the framework offers only a static overview of all elements involved in information systems. Then, in order to understand the many relationships existing among the models and thus facilitating their instantiation, the framework and our proposed mapping have to be completed by the workflow presented on Figure 12 that shows the information provided by each model and used by others. It represents a dynamic view related to a development project the IEC 62264 models have instantiated. The product information traceability application (comprising the two services related to backward and forward traceability (see section 2) is then fulfilled by merging the information coming from all IEC 62264 models, each of them related to different key players in the enterprise together with real-time information coming from the functioning enterprise.

The next section applies our approach to a case study related to an enterprise that makes and packs bags of flour. That enterprise needs a better traceability of their products in order to better improve customers' relationships when a defect happens in the flour making process. 


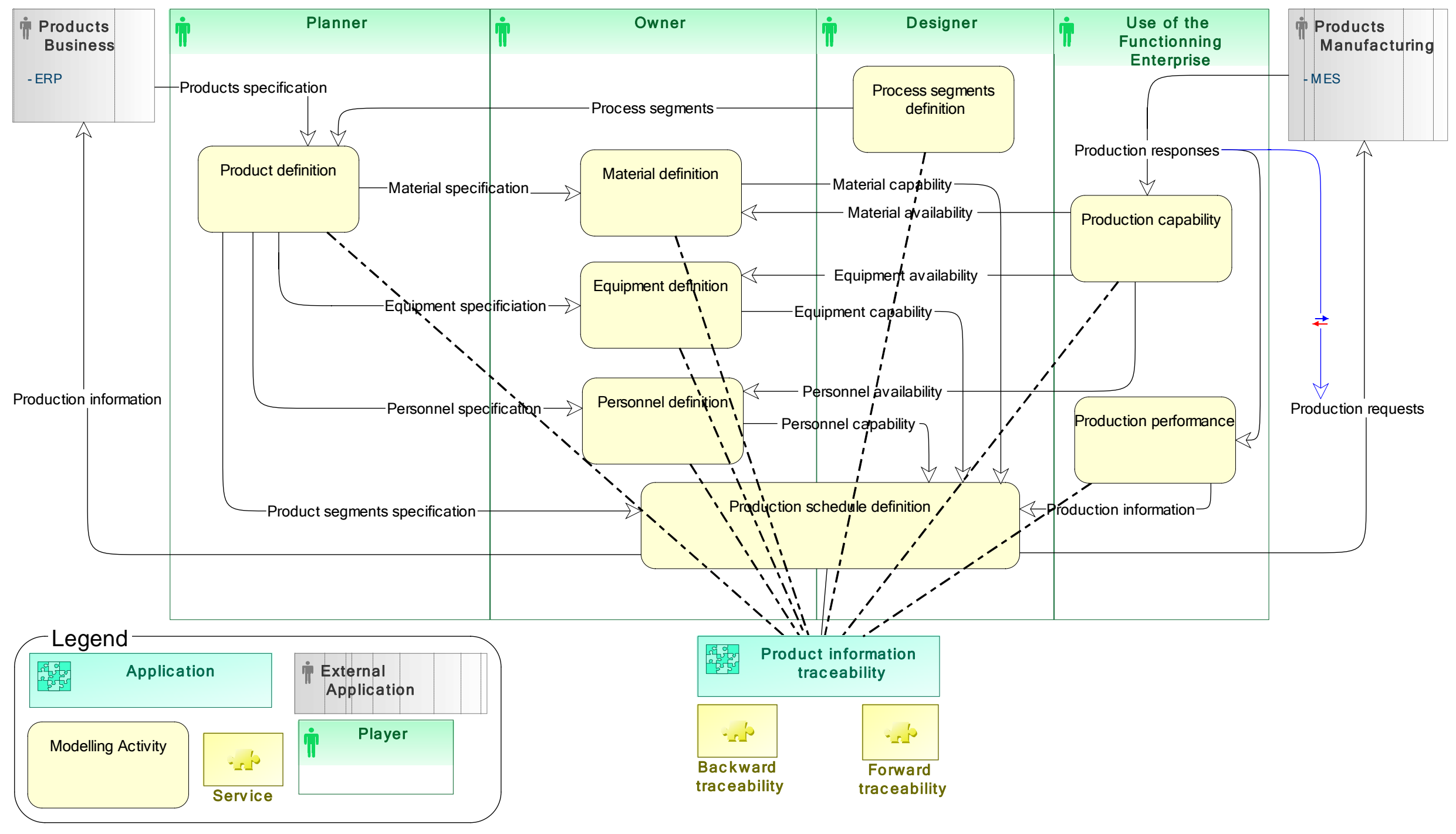

Figure 12: The IEC 62264 modelling framework workflow 
Panetto H., Baïna, S., Morel G. (2007). Mapping the IEC 62264 models onto the Zachman framework for analysing products information traceability: a case study. Journal of Intelligent Manufacturing, Springer Verlag, ISSN 0956-5515, à paraître

\section{CASE STUDY}

The proposed case study concerns a company that produces bags of flour by transforming wheat into flour and packing them into bags of $50 \mathrm{Kg}$. This company would like to model its bagging system in order to define all information objects that relate to the many products, resources and processes involved in the production of filled bags. These entities will be the base for developing a database for products information traceability. Hence, we study the bagging system, and instantiate the IEC 62264 standard models from different players’ perspectives following the Zachman framework. In this paper, we focus mainly on partial instantiation of models especially regarding the planner (Figure 13), the owner (Figure 14) and the designer (Figure 15) views.

\subsection{The planner's view:}

As stated in section 5, the planner's objective is to answer to the question: "What is important for the enterprise?” with regard to the six perspectives (What, How, Where, Who, When, Why). For the sake of simplifying the explanation in this paper, we are showing and detailing only the three first questions in relationship to the Product Definition model as defined in the IEC 62264 standard. Following the modelling framework shown on Figure 12, the planner has to define the scope of the system (Figure 13) and starts by instantiating the "ProductDefinitionType" regarding the final product that will be produced by the system (What), that are "Flour Bags". Then the planner defines the generic equipment required to produce these bags through instances of "EquipmentSpecificationType” (Where). Finally, the planner specifies the processes needed for producing flour bags (How). At this stage, we know what products the system will produce, how it will produce them and the specification of resources. For each of these elements, traceability information may be stored for later use in the product lifecycle phases. 


\subsection{The owner's view:}

The owner of the system has now to specify the enterprise model (Figure 14) defining the specific resources hierarchies available for this system. These resources are materials (raw, finished ...) (What), equipment and locations (Where) and People (Who). Materials are instances of "MaterialDefinition" that link to instances of "MaterialDefinitionProperty" which characterise them. Equipment are instances of "Equipment" that link to instances of "EquipmentProperty" and "Location". These instances are then linked to the specifications defined by the planner to map the planner requirements with the system available resources. The resulting model then specifies the resources (materials, equipments) available to produce. Each of those resources has properties that are stored for traceability purpose.

\subsection{The designer's view:}

Finally, the system designer should have (or will have) built the system in order to allow the production of different kind of products and, then shall model (Figure 15) the system processes ("ProcessSegmentType”), their inputs (consumed materials) and outputs (produced materials) (“SegmentSpecificationMaterial”), the supported equipments ("SegmentSpecificationEquipment”) and people (“SegmentSpecificationPersonnel”). These resources are linked to the available resources as defined by the owner in the enterprise model. The resulting model is, of course, linked to the owner model (enterprise model) but also records traceability information related to the different products instances that are produced by the system.

All these instances of IEC 62264 models will then define a conceptual model that may be derived to produce a relational model for implementing a database to record information regarding the products, the processes and the resources along the product lifecycle in order to provide both forward and backward information traceability (see section 2). 


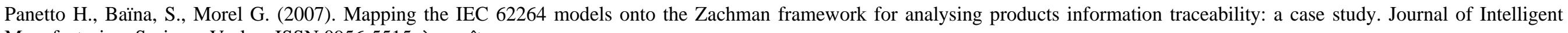
Manufacturing, Springer Verlag, ISSN 0956-5515, à paraître

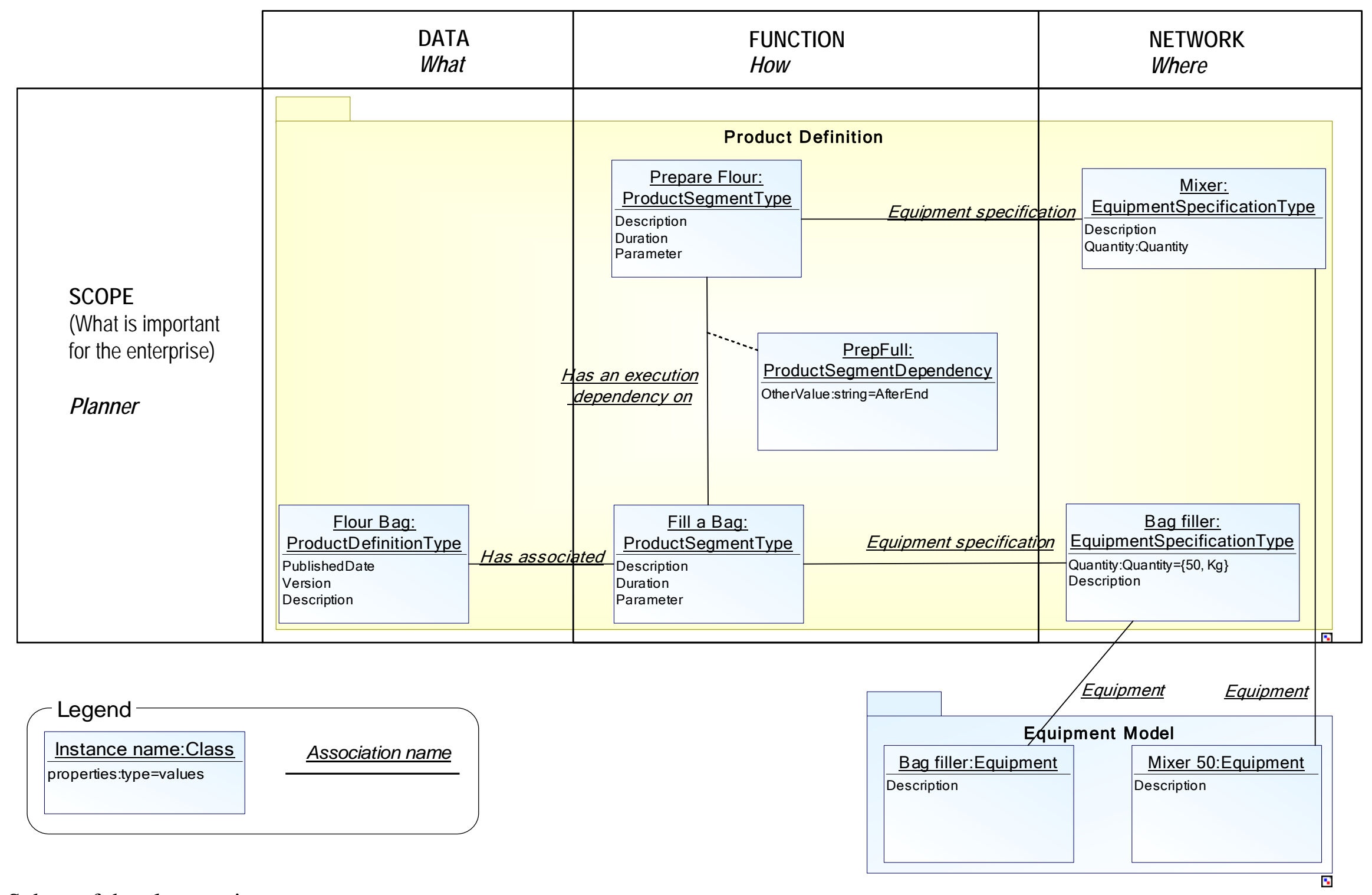

Figure 13: Subset of the planner view 

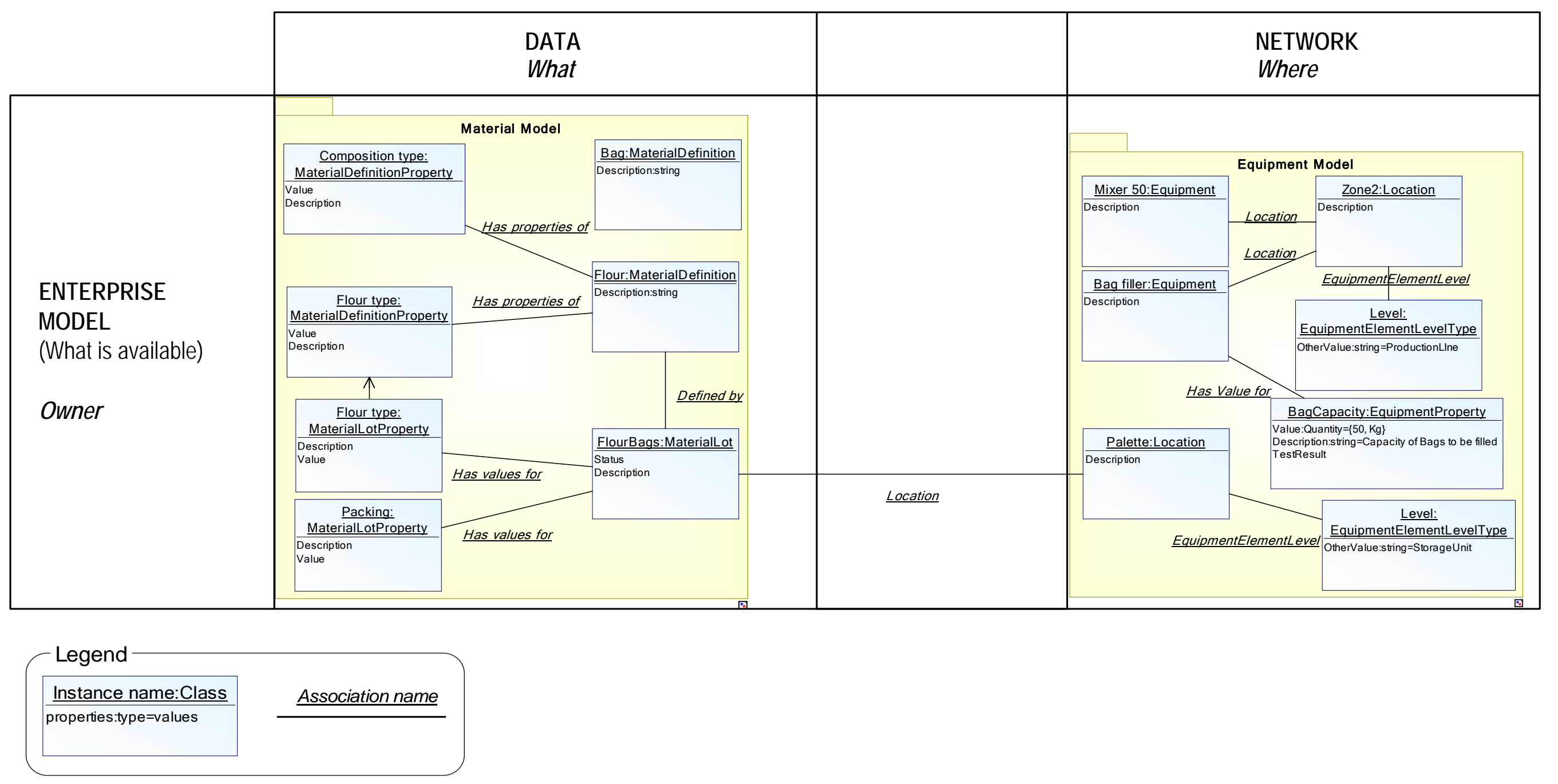

Figure 14: Subset of the owner view 
Panetto H., Baïna, S., Morel G. (2007). Mapping the IEC 62264 models onto the Zachman framework for analysing products information traceability: a case study. Journal of Intelligent Manufacturing, Springer Verlag, ISSN 0956-5515, à paraître

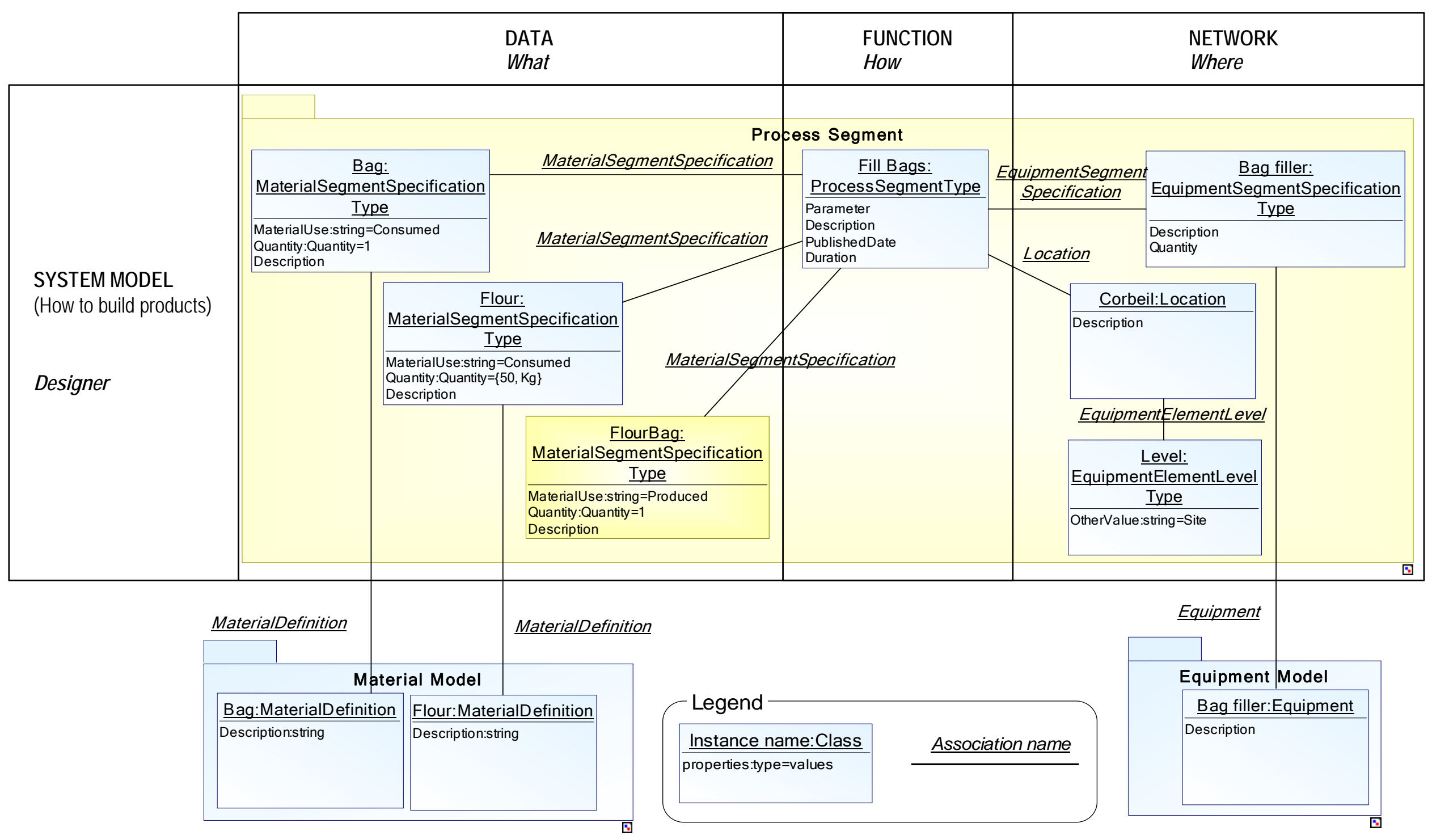

Figure 15: Subset of the designer view 
The current instantiation of the IEC 62264 models is then used as the base for feeding a product information traceability database implementing the standard. This implementation is based on the B2MML (Business To Manufacturing Markup Language) ${ }^{1}$ developed by the World Batch Forum. The Zachman Functioning View models the runtime information retrieval from the manufacturing processes (Production capability and performance models) that fills the database for enabling both backward and forward traceability services.

\section{CONCLUSION}

The paper proposed a mapping of IEC 62264 standard models onto the Zachman framework. The objective was, based on the recursiveness of the framework, to define a specific perspective of the framework dealing with the players view. The framework is not strict and rigid but there is the possibility of applying the logic of the framework to the framework itself, recursively at each abstraction level (Sowa and Zachman, 1992).

The IEC 62264 standard models are complex because they are generic to any kind of application domains. Thus, our approach and methodology helps modellers to understand these domains and facilitate their instantiation. The Zachman framework proposes general views about what a player should take into account when developing a system but its views need to be made concrete by mapping each row on specific models. Our mapping together with a modelling framework workflow then defines a methodology and a systematic approach. This approach supports the different players in the product and process modelling for instantiating the IEC 62264 models. It then defines product lifecycle information models for traceability. The result of this modelling approach is the emergence of all information objects that deal with product information along its life cycle.

We applied our proposed methodology to an industrial case study showing then its practicability and completeness. Our ongoing work is to populate a database implementing the standard with the information objects coming from this application.

\footnotetext{
${ }^{1}$ B2MML : Business To Manufacturing Markup Language, World Batch Forun, http://www.wbf.org
} 
Panetto H., Baïna, S., Morel G. (2007). Mapping the IEC 62264 models onto the Zachman framework for analysing products information traceability: a case study. Journal of Intelligent Manufacturing, Springer Verlag, ISSN 0956-5515, à paraître

8 REFERENCES

Baïna S., Panetto H., and Morel G. (2005), Holon-oriented B2M process modelling approach for applications interoperability in manufacturing systems environment, Proceedings of the IFAC World Congress, July 4-7, Prague, Czech Republic, ISBN: 0-08-045108-X

Bézivin J. (2004). In search of a Basic Principle for Model Driven Engineering, Novatica/Upgrade, $\quad$ Vol. $\quad \mathbf{V}, \quad \mathbf{N}^{\circ} 2$, April, pp. 21-24, http://www.upgradecepis.org/issues/2004/2/upgrade-vol-V-2.html

Cheng M.L. and Simmons J. E. L. (1994). Traceability in manufacturing systems. International Journal of Operations and Production Management, 14, 4-16

C4ISR Architecture Framework Version 2.0 (1997). Office of the Assistant Secretary of Defense for Command, Control, Communications and Intelligence, Washington D.C., November

delaHostria E. (2005). Manufacturing Application Integration Scheme using ISO 15745 and IEC 62264. Proceedings of the IFAC World Congress, July 4-7, Prague, Czech Republic, ISBN: 0-08-045108-X

IEC 62264 (2002). IEC 62264. Enterprise-control system integration, Part 1. Models and terminology, Part 2: Model object attributes. ISO/IEC, Geneva

ISO IS 15704 (2000). ISO/IS 15704:2000 Industrial automation systems-Requirements for enterprise—reference architectures and methodologies, ISO, Geneva, Switzerland

ISO 15745-1, (2003) Industrial automation systems and integration - Open systems application integration framework - Part 1: Generic reference description. ISO, Geneva, Switzerland

Frankel D. S., et al. (2003). The Zachman Framework and the OMG's Model Driven Architecture. Business Process Trends Whitepaper, September, http://www.bptrends.com Jansen-Vullers J., van Dorp A., and Beulens B. (2003). Managing traceability information in manufacture, International Journal of Information Management, 23, 395-413 
McFarlane D., Sarma J., Chirn G., Wong J., Ashton A. (2003). Auto-ID systems and intelligent manufacturing control, Journal of Engineering Applications of Artificial Intelligence, 16, $365-376$

Mellor S.J., Kendall S., Uhl A. and Weise D. (2004). Model Driven Architecture, AddisonWesley Pub Co, March, ISBN: 0201788918.

Morel G., Panetto H., Zaremba M.B. and Mayer F. (2003). Manufacturing Enterprise Control and Management System Engineering: paradigms and open issues. IFAC Annual Reviews in Control. 27/2:199-209, December

Noran O. (2003). An analysis of the Zachman framework for enterprise architecture from the GERAM perspective. IFAC Annual Reviews in Control. 27/2:163-183, December

Osvalds G. (2003). Use of UML in Modeling Enterprise and Systems Architecture. INCOSE Chesapeake Chapter Meeting, Columbia, August

O'Rourke C., Fishman N. and Selkow W. (2003). Enterprise Architecture Using the Zachman Framework,, Thomson Learning, Inc. Boston, MA. ISBN: 0-619-06446-3. April

Sowa J. F. and Zachman J. A. (1992). Extending and Formalizing the Framework for Information Systems Architecture, IBM Systems Journal, 31/3, 590-616

Sowell P. K. (1999). Consolidated Mapping of C4ISR Framework Products to Federal Framework Models. The MITRE Corporation, McLean, Virginia.

Terzi S. (2005). Elements of Product Lifecycle Management: Definitions, Open Issues and Reference Models, PhD dissertation, University Henri Poincaré Nancy I and Politecnico di Milano, May 25th

Terzi S., Cassina J., and Panetto H. (2005). Development of a metamodel to foster interoperability along the product lifecycle traceability. Proceedings of the IFIP/ACM INTEROP-ESA conference, February 23-25, Geneva, Switzerland, Springer Science publisher, pp. 1-11, ISBN: 1-84628-151-2

UML (2005). Unified Modeling Language. UML 2.0 Superstructure, v2.0 formal 05/07/04. OMG 
Panetto H., Baïna, S., Morel G. (2007). Mapping the IEC 62264 models onto the Zachman framework for analysing products information traceability: a case study. Journal of Intelligent Manufacturing, Springer Verlag, ISSN 0956-5515, à paraître

Zachman J. A. (1987). A Framework for Information Systems Architecture, IBM Systems

Journal, 26/3, 276-295

\section{ACKNOWLEDGEMENT}

The authors would like to thank the enterprise Groupe Soufflet, and more specially Françoise

Entzmann, for the application support used in this work.

List of figures

Figure 1: Product-centric paradigm (adapted from (Baïna, et al., 2005)................................4

Figure 2: Functional hierarchy as defined in IEC 62264 ......................................................

Figure 3: The IEC 62264 models hierarchy (IEC 62264, 2002) ...........................................

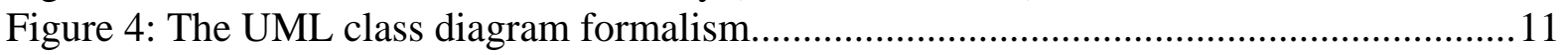

Figure 5: The conceptualised IEC 62264 Product Definition model......................................12

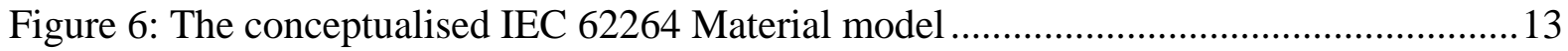

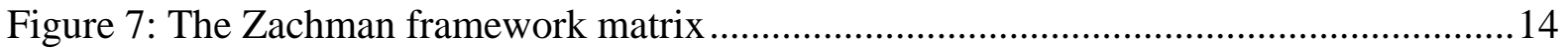

Figure 8: IEC 62264 standards on the Zachman abstraction view .....................................16

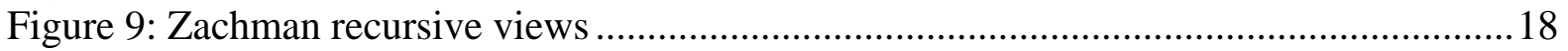

Figure 10: IEC 62264 models mapped onto the Zachman framework players view...............20

Figure 11: The Zachman framework as a filter for views definition of products information

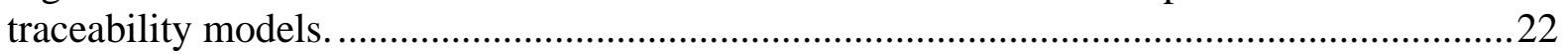

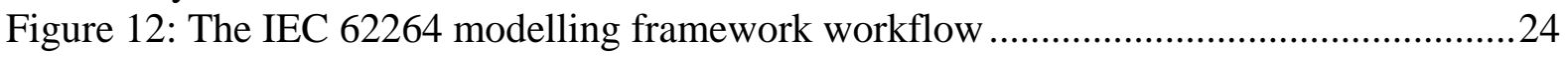

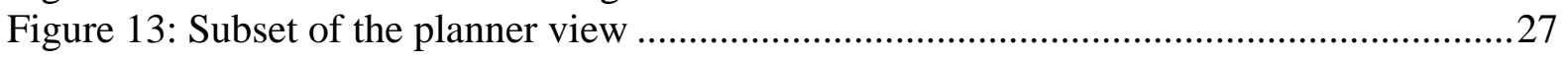

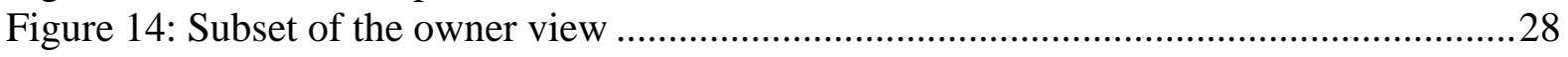

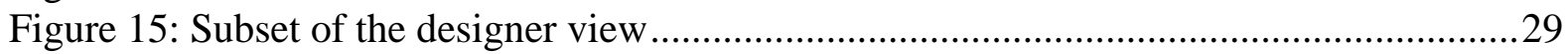

